\title{
Polémica, controversia y críticas contra los cristianos en los escritos mandeos
}

Controversy, controversy and criticism against Christians in the Mandaean writings

Jesús Galisteo Leiva g.1.jesus@ hotmail.com Universidad de Cádiz

España

\section{Resumen}

En este artículo expondré cuáles son los principales temas de conflicto y controversia en la polémica anticristiana de los mandeos que podemos apreciar a través de sus textos religiosos (principalmente, los dos libros del Ginza y su corpus de oraciones rituales y litúrgicas), prestando especial atención en las críticas a los movimientos monacales y clericales y sus formas de ascetismo, así como el trato que reciben en el pensamiento y credo mandeo los personajes comunes entre ambas religiones (Dios Padre, Espíritu Santo, Cristo, María y, por supuesto, Juan Bautista), tan diferente al cristiano, consecuencia de consecuencia de siglos de sincretismo relativamente pacífico, pero también de una tensa y hostil convivencia histórica entre ambas religiones.

Palabras clave: Mandeísmo, Anticristianismo, Ginza, herejía, gnosticismo.

\begin{abstract}
In this article I shall explain the major issues of conflict and controversy in Mandaean anti-Christian polemic, which can be seen in their religious texts (mainly the two books of Ginza and their corpus of ritual and liturgical prayers). I will pay special attention to the criticism of monastic and clerical movements and the forms of asceticism, as well as how common figures in both religions (God the Father, the Holy Spirit, Christ, Mary and of course John the Baptist) are treated in Mandaean creeds and beliefs. This is quite different from Christianity and is a result not only of centuries of relatively peaceful syncretism but also of a tense and hostile historic coexistence between the two religions.
\end{abstract}


Keywords: Mandaeism, Antichristianism, Ginza, heresy, Gnosticism.

\section{Sumario}

El presente artículo consta de tres secciones principales (1. Sincretismos y conexiones; 2. Ginza; 3. Oracional mandeo), precedidas de una introducción (0) explicativa de qué es el mandeísmo, ya que en la historiografía y cultura española esta ha sido omitida y olvidada y cuyo desconocimiento se ha roto, en parte, a causa de las persecuciones religiosas ocasionadas por los conflictos internacionales actuales (guerra de Irak, terrorismo islámico, aparición del llamado Estado Islámico) y, finalmente, unas conclusiones (4) que abordan, de forma sumaria, el problema poliédrico anticristiano presente en los principales escritos mandeos (razones, elementos de rechazo y aceptación en la configuración del mandeísmo respecto a las ideas y personajes propios del cristianismo, etc.). Las fuentes quedan señaladas bajo el epígrafe (5) y la bibliografía en el (6).

\section{Introducción.}

El mandeísmo, una religión gnóstica a medio camino entre el judaísmo y el cristianismo, nacido como secta herética del judaísmo antiguo, llamados por los escritores antiguos bajo diversos nombres a causa del desconocimiento que se tenía de ellos (nazoreos, nazoraios, nasaeaios, nazario, noseri, ebionitas, hemerobaptistas, mandeos, sabeos ${ }^{1}$, etc.), que, en definitiva, todos designaban a una misma realidad, una o varias sectas judaicas con características gnósticas ${ }^{2}$ comunes agrupadas en la cuenca del Jordán, algunas previas al nacimiento de Cristo, que con el tiempo terminarán, si no todas, parte de estas sectas, por asumir ideas cristianas y algunos personajes neotestamentarios en su cosmovisión particular, aunque asignándoles valores diferentes

\footnotetext{
${ }^{1}$ Conocidos con este último nombre en el mundo islámico son una de las tres religiones del libro que según los preceptos musulmanes deben ser toleradas y protegidas, pese a que la búsqueda de la ortodoxia unida a las persecuciones esporádicas de mayor o menor intensidad dadas a lo largo de la historia contra este grupo han provocado la irrupción de sus propias reglas de convivencia con otras religiones. El Corán los menciona en los suras $2{ }_{62} 5_{69} 22$ 17. Ver, además, ALKHALIFA, W. S., 2010, 123- 129.

${ }^{2}$ Hans Jonas, que define al mandeísmo como "una secta, tan violentamente anticristiana como antijudía", la valora con una alta estima pues "este es el único ejemplo de existencia continuada de la religión gnóstica hasta nuestros días. El nombre de la secta deriva del arameo manda, <<conocimiento >>, de forma que <<mandeos >> significa literalmente <<gnósticos>>”. JONAS, 2003, 68.
} 
y, algunos, claramente contrapuestos a las creencias cristianas y católicas en particular. Aunque el conjunto de sus creencias gnóstico- baptistas son muy antiguas, su desarrollo e impronta histórica como comunidad religiosa independiente tendrá lugar entre los siglos I y II d. C.

Los mandeos, olvidados, marginados y perseguidos a lo largo de la historia han sobrevivido a múltiples avatares históricos hasta la actualidad ${ }^{3}$. Las persecuciones, la guerra y las epidemias han causado a lo largo de más de dos mil años de existencia de esta religión étnica una profunda herida difícil de sanar, pero aún así resisten a desaparecer de la historia, aunque hoy día pocos se acuerden de ellos. Circunscritos a un espacio geográfico excesivamente concreto a lo largo de milenios, como es Irak e Irán, países de idiosincrasia religiosa por antonomasia de los que las persecuciones y la guerra se niegan a marcharse, en la actualidad han sido diezmados, en un holocausto contra el pueblo mandeo, cuyos pocos miembros supervivientes han tenido que marcharse a países europeos y americanos que actualmente ofrecen mayor seguridad y tolerancia para estas minorías religiosas y étnicas, como son Alemania y Estados Unidos.

Debido a que su pervivencia histórica motivó que se enfrentara en multitud de controversias con judíos, cristianos y musulmanes, en este artículo examinaré, a través de los textos procedentes del mandeísmo, cuáles son los temas, críticas y preocupaciones principales de los escritos de esta secta judaica tan antigua, con respecto al cristianismo.

Obviamente, una religión con tantos milenios de historia a sus espaldas generó una multitud de escritos con un amplio abanico temático, algunos de los cuales son de difícil datación, por lo que no delimitaré este estudio a una época determinada, abriendo así, este artículo a una aproximación general sobre la controversia mandeo- cristiana en su sentido cronológico más amplio posible.

Sirva, así, este artículo, como introducción al estudio de una religión olvidada pero viva en la actualidad, a la vez que un sentido homenaje para todas aquellas personas que la

\footnotetext{
${ }^{3}$ Persecuciones musulmanas desde el siglo XIV, pasando por las del siglo XVIII, hasta la actualidad perpetrados por extremistas islámicos, han diezmado la población mandea. Además, en 1831, una peste exterminó la clase sacerdotal, provocando un corte en la transmisión de la cultura mandea (el sacerdocio era hereditario) y teniendo que ser sustituidos por laicos que ni siquiera sabían la lengua de sus escrituras sagradas. LÓPEZ FERNÁNDEZ, 2013, 43- 44.
} 
profesan y siguen sometidas a la persecución y la guerra, lacra de este mundo al que todos los seres humanos estaremos sometidos desde nuestros orígenes como sociedad y que ha castigado tanto a Oriente próximo.

Enrique López Fernández (2013), argumenta que "la polémica anticristiana, tan acusada y en ocasiones feroz, más bien parece deberse a su contacto con los cristianos, tal vez los nestorianos, ya en su estancia en Mesopotamia, motivada por el afán de estos de convertirlos, a toda costa, a la fe cristiana" (p.41). En cualquier caso, el sincretismo, o simplemente, la apertura de este grupo religioso venido del judaísmo oficial, hacia el cristianismo, tal vez ideadas como forma de supervivencia durante el tiempo en que Mesopotamia estuvo bajo el yugo del Imperio romano cristiano, motivaron aún más su marginación como grupo religioso independiente, fuera del judaísmo, como secta herética que era desde sus orígenes, y rechazado por el cristianismo, pues ni eran ya judíos ni cristianos ante las autoridades religiosas cristianas. Evidentemente, el trato que le brindaron los musulmanes fue peor, pues no podían reconocer a esta secta independiente ni en una ni en otra religión del Libro, es decir, su indefinición sincrética a ojos musulmanes, no les hacían ni judíos ni cristianos. Por lo que López Fernández (2013) concluye "marcados los mandeos por el sino de la persecución, primero por parte de los judíos, luego de los cristianos y finalmente de los árabes, vivieron siempre en condiciones de precariedad"(p.42).

\section{Sincretismos y conexiones}

En primer lugar, no podemos acercarnos a la controversia anticristiana presente en los escritos mandeos sin observar, al menos de forma sumaria, cuáles son los nexos o puntos de encuentro, en gran parte sincréticos al tener que adaptarse los mandeos al cristianismo por la presión que católicos y nestorianos ejercieron sobre ellos para que se convirtieran hasta la irrupción del islam en sus comunidades y en la historia de Irak e Irán.

Es evidente que el mandeísmo sostiene una cosmovisión gnóstica, de confesión monoteísta, aunque no se ha separado completamente de su originario politeísmo de corte henoteísta y altamente sincrético, uniendo conceptos judíos primitivos, 
aportaciones de la filosofía griega platónica ${ }^{4}$ y personajes de valoración contrapuesta tomados del cristianismo.

En primer lugar, dentro de la jerarquía de sus dioses o fuerzas divinas encontramos al Ser Supremo, denominado Vida ("La Vida es sencillamente Dios"), Mana (alma o divinidad), Rey de la luz, Rey del aire, Señor de la grandeza, etc. Esta divinidad lidera al resto de seres sobrenaturales, siendo el equivalente a la hipóstasis del Dios Padre de los cristianos (López, 2013, 58- 59)

El sistema jerárquico- estructural de la trinidad, presente también en el paganismo como forma de culto ${ }^{5}$, lo encontramos en el mandeísmo, tomado probablemente del sistema de pensamiento cristiano, siguiendo el esquema padre, hijo y nieto; las llamadas Primera, Segunda y Tercera Vida, más una Cuarta Vida nunca llamada como tal. Añadida, probablemente, para romper el sistema trinitario y completar el dualismo propio del gnosticismo al que pertenece el mandeísmo. (López, 2013, 63-64)

El mandeísmo pudo influir incluso en el nacimiento y desarrollo de algunas sectas heréticas cristianas como el maniqueísmo, compartiendo ambas su sentido dualista y gnóstico del Universo.

Existen a su vez una jerarquía de ángeles y demonios que, aunque mucho más numerosos que en el cristianismo, sigue siendo un punto de unión. Entre la abundante angeología mandea encontramos a un espíritu compartido por el judaísmo, el cristianismo y el islam que a todos les resulta familiar por su importancia en la historia de estos tres monoteísmos, el ángel Gabriel ${ }^{6}$. (López, 2013, 66)

Poseen, además, una concepción escatológica de cielo e infierno, con multitud de purgatorios por los que el alma (mana) debía pasar antes de purificarse totalmente y

\footnotetext{
${ }^{4}$ El demiurgo platónico es asimilado en el mandeísmo teniendo un papel fundamental en la creación, acto de ambivalencia negativa y positiva a la vez, recibiendo el nombre de Ptahil. Este nombre es posible que sea un préstamo egipcio, negativo o devaluado del dios Ptah. Pthahil es la Cuarta Vida, aunque nunca se lo denomina como tal en los escritos mandeos. Etimológicamente su nombre deriva de del dios artesano egipcio Ptah al que ha de sumársele el sufijo semítico $-i l,(\langle\langle$ dios $\rangle)$, designando así su naturaleza divina. Igualmente, Abatur, pesador de las almas es un sustitutivo o alter ego de Osiris en el juicio escatológico fundamental de la religión egipcia.

${ }^{5}$ Por ejemplo, en el mundo romano encontramos la tríada aventina, precapitolina y capitolina. Para conocer con mayor profundidad el mundo de las tríadas divinas en el mundo romano (pues existen en múltiples religiones más allá del marco territorial romano), ver BAYET, 1984, 59, 66, 133 y 139 (para las tríadas divinas en general); 23, 133 y 139 (para las romanas del Aventino); 23, 51, 66, 97, 105, 133 y 216 (para las romanas del Capitolino); 59 y 235 (asiáticas); 242 (iranias); 235 (sirias); 217 (célticas).

${ }^{6}$ En el caso del mandeísmo, se le relaciona en algunos textos con la creación, por encargo del Rey de la Luz o de la Magna Vida.
} 
volver limpio hasta el reino celestial lleno de luz del Mana o Ser Supremo. Para este final glorioso en el más allá, u otros no tan aciagos, la gnosis, la moral y las obras jugaban un papel destacado. Todo ello, común al conjunto de creencias cristianas tardías con las que tuvo contacto el mandeísmo. Además, este sistema de creencias ultraterrenas enlaza con la visión cosmológica de los gnósticos, y obviamente, el mandeísmo no puede quedar fuera de esta estructura de pensamiento, tal y como afirma Hans Jonas (2003, p.82):

Esta multiplicación de sistemas demoníacos, a los cuales la vida irredenta está condenada, constituye uno de los temas de las numerosas enseñanzas gnósticas.

Los $<<$ mundos $>>$ de los mandeos se corresponden con los $<<$ eones $>>$ del gnosticismo helenístico. Normalmente hay siete o doce (que se corresponden a su vez con el número de planetas o de signos del zodíaco), si bien en algunos sistemas la pluralidad prolifera hasta alcanzar vertiginosas y aterradoras dimensiones, 365 <<cielos>> o los innumerables <<espacios>>, $<<$ misterios $>>$

(aquí utilizados en su sentido topológico), y <<eones〉> de Pístis Sophía. La $<<$ Vida $>>$ debe pasar por a través de todos ellos (representantes de la multitud de grados que nos separan de la luz) para encontrar la salida.

El componente mesiánico de Manda d- iiia $^{7}$, salvador mandeo, cuyo nombre significa “Conocimiento de la Vida”, por el carácter gnóstico de la secta, pese a no poseer unos orígenes históricos como los de Jesús de Nazaret, los hechos legendarios que se les atribuye, así como su significación mesiánica o están inspirados directamente en la figura neotestamentaria de Cristo o poseen nexos comunes a otras figuras salvadoras de componente semítico que hacen ambos personajes prácticamente idénticos. No obstante, hay que señalar que son personajes religiosos claramente diferenciados en el

\footnotetext{
${ }^{7}$ Ginza, II, XXIV. Manda d-hiia (Conocimiento- de- la Vida) es el hijo primogénito de Mana (Vida) y enviado al mundo de las tinieblas y puso orden allí; o, lo que es lo mismo en el cristianismo: Jesús es el primogénito de Dios Padre y tras la muerte por crucifixión descendió a los infiernos y resucitó al tercer día.
} 
mandeísmo. Aunque nosotros veamos semejanzas entre Manda d-hiia y Cristo, para los mandeos el primero es un ser salvador y claramente positivo y el segundo, nacido de Espíritu Santo, un ser femenino nacido de una estirpe maligna de un inframundo acuático $^{8}$, se le atribuyen características negativas y perniciosas para los hombres que, lejos de salvarlos, los seduce en su secta para apartarlos del Mana o Vida.

Entre las semejanzas en las tradiciones de Manda $d$ - hiia y Cristo, que son muchísimas para poder ignorarlas o pasar algún elemento por alto, encontramos: ambos curaron leprosos y devolvieron la vista a los ciegos, fueron bautizados por Juan el Bautista en el Jordán, Conocimiento de la Vida es el Adakas mandeo u hombre ideal y Jesús de Nazaret es el Hijo de Hombre en el pensamiento cristiano, en el mandeísmo se administra el bautismo en nombre de Manda $d$ - hiia y en el cristianismo en el nombre de Jesucristo, ambos, en sus diversas tradiciones ascendieron a los cielos, ambos vivieron en tiempos de Poncio Pilato, etc. (López, 2013, 67-68)

Manda d-hiia entra en competencia con Cristo y lo vence en una tradición tardía surgida en el marco contextual de la controversia anticristiana y nestoriana.

El salvador mandeo será tratado bajo los mismos símbolos que el cristiano: pescador de almas, buen pastor ${ }^{9}$, así como la divinidad será presentada como hortelano ${ }^{10}$.

Incluso podemos encontrar en la liturgia de ambas religiones, mandea y cristiana, una eucaristía para el ritual de comunión ${ }^{11}$, que en el caso mandeo recibe el nombre de Pihta. Por lo tanto, son dos los sacramentos fundamentales compartidos, el bautismo ${ }^{12} \mathrm{y}$

\footnotetext{
${ }^{8}$ De aguas negras, símbolo del caos primordial.

${ }^{9}$ Ginza, II, XXVII.

${ }^{10}$ La imagen del hortelano que cuida de su jardín, alegoría de Dios cuidando del alma de sus fieles, fue muy utilizada por Santa Teresa de Ávila, introduciendo con fuerza este elemento simbólico en la tradición espiritual del Siglo de Oro. DE JESÚS, Libro de la Vida, 11- 22.

${ }^{11}$ El simposio, como acto religioso de comunión con la divinidad, los difuntos y la propia comunidad de fieles toma gran relevancia socio-religiosa en las religiones antiguas y, especialmente, en el mundo semítico. Ver, SMITH, 2009.

${ }^{12}$ La importancia de los bautismos constantes y de los ritos de limpieza repetitivos, casi obsesivos, hizo que a esta secta herética del judaísmo se la denominara hemerobaptistas. "Hemerobaptistae [qui coditie corpora sua et domun et supellectile lavant] [eo quod cotidie vestimenta sua et corpora lavent]" "Los hemerobaptistas [son aquellos que lavan diariamente sus cuerpos, su casa y su vestido]. [Reciben este nombre por lavar a diario sus vestiduras y su cuerpo]". Isid. Etym. VIII, 4, 11; aunque la erudición de Isidoro de Sevilla recoge a la perfección la esencia del recuerdo que quedó en el saber latino de esta secta véase también testimonios anteriores como las fuentes griegas tales como Epifanio de Salamina, que también resaltan la faceta purificadora de este grupo religioso, "But this sect had acquired this additional characteristic, of being baptized every day in spring, fall, winter and summer, so that they got thename of Hemerobaptists. For this sect alleged that there is no life for a man unless he is baptized daily with water, and washed and purifi ed from every fault. (...) And if they do not simply avoid sin, supposing that the
} 
la eucaristía, ambos centros esenciales de la vida cultual en estas religiones enfrentadas, y que, aún así, como en la mayoría de los conflictos religiosos, guardan tantas cosas en común que es más fácil ver éstas que las contraposiciones en que se basan sus puntos adversativos de ruptura y rivalidad.

El cumplimiento de estos ritos es fundamental para la culminación con éxito del viaje espiritual tras la muerte en su contexto soterológico y escatológico mandeo:

Pero para lograr la ascensión (masiqta) no basta solo con el conocimiento de la gnosis, se requiere, además de las buenas obras, la eficacia purificadora y santificadora (comunión con la Vida) de unos sacramentos y ritos, entre ellos y sobre todo el bautismo y una especie de eucaristía, a las que se atribuyen una cierta participación en las propiedades de la vida divina (luz, verdad y vida) por parte del que las recibe. Pero, aún así, la presencia del Salvador o Mensajero es todavía necesaria para salvar las <<estaciones〉> de los poderes malignos, atravesar los torrentes que separan el mundo de la luz y el mundo de las tinieblas y entrar así en la región de la luz. Es el acompañante o guía (paruanqa) que le muestra el camino de la verdad (dirka d-Kusta) y le conduce a la victoria (zakuta). (López, 2013, 150-151)

Los elementos astrológicos, con un valor marcadamente opresor por ejercer con su determinismo una coacción evidente a la libertad de decisión de los seres humanos y los mandeos como pueblo santo en particular, posee una curiosa semejanza numérica con el judeocristianismo, donde nada es asignado al azar. Los Siete, es decir, los siete planetas de su universo astrológico y los Doce, o doce signos del Zodíaco; son claras alusiones al valor negativo asignado al siete como número de perfección en la gematría judeocristiana y a las doce tribus de Israel y los doce Apóstoles, asignando a ambas

water will cleanse them as they keep sinning every day, their supposition is of no use and their deed is undone and come too late. (4) Neither Ocean nor all the rivers and seas, the perennial streams and brooks and all the water in the world, can wash away sin, for this is not reasonable and is not by God's ordinance. Repentance cleanses, and the one baptism, through the pronouncing of the Name in the mysteries". Epiph. Const. Haer. I, 17; 1, 1- 2, 3. 
tradiciones (judía y cristiana), de forma subliminal, a través de la numerología, unas connotaciones intrínsecamente malvadas.

Continuando con esa línea de semejanzas doctrinales compartidas entre el mandeísmo y el cristianismo encontramos un apocalipsis o fin del mundo, pero que para los mandeos se separaba en dos partes principales: una división de los tiempos futuros y un elemento escatológico no común al corpus de creencias mandeas.

Para los mandeos, 6.000 años de su historia estarían dominados por el reinado del "falso Mesías", es decir, por el cristianismo, seguido de un tiempo menos prolongado de 5.000 años de paz. El otro factor es la excepcional alusión a la resurrección de los muertos en los escritos mandeos.

A continuación, expondré cuáles son las alusiones más destacadas acerca de la polémica religiosa mandea- cristiana y sus principales temas, críticas y preocupaciones, en un marco contextual brevemente comentado presentes en los principales textos religiosos mandeos.

\section{Ginza}

El Ginza es el libro más importante de todos los escritos mandeos, cuyo título se traduce por "Tesoro". Está dividido en dos partes, el llamado Ginza Derecha y el Ginza Izquierda. Pese a la antigüedad evidente del texto, en Europa contamos con un ejemplar muy tardío, fechado en 1560 .

Las críticas anticristianas en los escritos mandeos se estructurarán entre el desprestigio a la persona de Cristo en un plano histórico- religioso e interrelacionado con él a los fieles cristianos. Las acciones de los fieles de Cristo respecto a las comunidades mandeas repercutirán directamente sobre la concepción que éstas tengan de la segunda hipóstasis de la Trinidad (según la percepción cristiana). La progresiva evolución cristológica, así como sus múltiples facetas, se centrarán en mostrar al Nazareno como un ser perverso, embaucador y mentiroso, digno de la maldad de su infernal madre, Espíritu Santo. A veces, la crítica mandea anticristiana no distingue entre su Dios y los fieles que profesan dicha religión, apareciendo ambas claramente interconectadas.

La primera alusión a la controversia anticristiana la encontramos en un fragmento que hace alusión a las formas impositivas de la fe que usaban algunas religiones 
mayoritarias, ya fuera usando métodos violentos o por la convicción pacífica. En esa lista, compuesta por las religiones astrales, judaísmo, cristianismo e islam; marco repetido a lo largo de los textos apologéticos y combativos contra las religiones que los oprimieron históricamente a lo largo de los textos mandeos que hacen referencia al marco cultual ajeno. En concreto, en esta gran obra religiosa mandea la primera referencia a esta polémica anticristiana dice así: "Hay entre ellos quienes los extravían con imágenes de oro y plata, con imágenes del crucificado, con ídolos de barro y con otras vanas obras"13.

Pero las críticas al cristianismo se desarrollarán más adelante. Aquí la imagen de Jesucristo depende, en gran medida, del papel opresor que jugaron los cristianos, ya fueran católicos o nestorianos, con respecto a los mandeos. Por ello, se presenta a Cristo Jesús como falso Mesías, señor de los astros -algunos de los cuales provocan lascivia y del Espíritu Santo (ser femenino y maligno que para los mandeos era madre de demonios y del propio Jesucristo). Asimismo, acaban por relacionar a sacerdotes no cristianos, que rendían culto a Marte, cuya caracterización era la de unos asesinos desolladores e idólatras. Finalmente, el autor previene a los fieles mandeos de Cristo ${ }^{14}$.

No solo atacan a la persona de Cristo, blasfemando contra la segunda hipóstasis de la Trinidad para combatir a sus seguidores, sino que continúa en esta línea combativa poniendo en cuestión la moralidad de los devotos cristianos, atacando de forma hiriente y francamente repugnante, soez y blasfemo para la sensibilidad de los católicos, que sublimaron como mayor grado de perfección religiosa la vida en castidad, ya fuera siguiendo un régimen de ascesis en la virginidad, en el celibato o cualquier forma eremítica o monacal entregada plenamente a la oración contemplativa, al autocontrol y vencimiento de las pasiones (carne, mundo y demonio), en definitiva, al culto, seguimiento e imitación de Cristo.

Los demonios de Mercurio, el Mesías, caen con astucia sobre los humanos; los separan de sus casas y de sus familias; los cautivan en los

\footnotetext{
${ }^{13}$ Ginza, I, I, 24.

${ }^{14}$ Ginza, I, I, 27- 29.
} 
montes y los alcanzan en los desiertos; los hacen habitar en solitario, y su estirpe y su semilla les fluyen por los muslos ${ }^{15}$.

Y vuelve sobre el tema de Cristo advirtiendo a los mandeos que Jesús no es Hibil Ziua, que éste no se reveló en tiempos de Jesucristo; acusa a Jesús de usar la magia ${ }^{16}$ y el engaño; salvaguarda a los mandeos de la apostasía en tiempos de persecución, probablemente por parte de las autoridades islámicas del momento, aconsejando que si obligan a los mandeos a estar con los cristianos digan que pertenecen al mismo culto, pero que en su interior no renuncien a su Señor, Rey de la Luz ${ }^{17}$.

Si para los mandeos Jesús no era ni Manda d- hiia, personaje mesiánico por excelencia, ni tampoco Hibil Ziua ${ }^{18}$, el Ginza I identifica al Jesús bíblico por Anus Utra ${ }^{19}$. De él se dice en esta obra que vino en tiempos de Pilatos y no en forma material ("y no vestido con vestidura corporal”), curó a leprosos y tullidos y resucitó muertos, predicó que había luz y tinieblas, convirtió a judíos y envió 360 profetas de Jerusalén a dar testimonio del nombre del Señor de la grandeza y, finalmente, ascendió a los cielos y se sentó sobre los elegidos de la Verdad. Y posteriormente, a estos acontecimientos, evidentemente tenidos como históricos, cayó Jerusalén en el año 70 durante el saqueo de Tito, seguido de la diáspora ${ }^{20}$, o en palabras del autor del Ginza I, “entonces fue destruida la ciudad de Jerusalén y los judíos salieron al destierro y fueron dispersados de ciudad en ciudad" 21 .

Para los mandeos, como los cristianos y los musulmanes, Cristo jugará un papel destacado al final de los tiempos. Los mandeos imaginaron que vendría caminando

\footnotetext{
${ }^{15}$ Ginza, I, I, 28.
}

${ }^{16}$ La magia estaba prohibida en el mandeísmo y es continuamente condenada en algunos de sus principales libros sagrados, pero aún así, la practicaron y formó parte de sus rituales religiosos. Ver LÓPEZ FERNANDEZ, 2013, 49- 50 y SCOTTEN, 2007, 28- 31.

${ }^{17}$ Ginza, I, I, 28.

18 "Otra tríada de seres celestes, o al menos de condición dudosa, es la compuesta por Hibil, Sitil y Anus, los tres adamitas, equivalentes a los personajes bíblicos Abel, Set y Enos. (...) particularmente destacada es la función de Hibil, llamado a veces Hibil Ziua y Mana Yauar, cuya acción (descenso al mundo de las tinieblas y vencedor de los poderes del mal, revelación primitiva y salvación) se equipara a la de Manda $d$ - hiia o a la de Adakas, el arquetipo celeste humano u hombre ideal divino". LÓPEZ FERNÁNDEZ, 2013, 66. En lo que refiere al personaje de Sitil ver BUCKLER, 2002, 35- 39.

${ }^{19}$ Tercera hipóstasis de la tríada celeste compuesta por Hibil, Sitil y Anus. LÓPEZ FERNÁNDEZ, 2013, 66.

${ }^{20}$ No hay referencias a la guerra judeo- romana iniciada por Nerón y concluida por Adriano, ni siquiera a la refundación de Jerusalén por el mismo emperador bajo el nombre de Elia Capitolina, en honor a su madre. Solo importa la caída de la ciudad y al exilio forzado como elementos histórico- teológicos, ya que su impronta fue mayor para las diversas sectas judías y cristianas supervivientes a tan dramático conflicto. ${ }^{21}$ Ginza, I, I, 29. 
sobre las aguas para hundirlos, es decir, convertirlos y arrastrarlos a la perdición. La prevención contra un Cristo de un plano exclusivamente escatológico pasa a materializarse en sus fieles cristianos y, el recuerdo de las conversiones forzosas al cristianismo, así como las persecuciones abiertas ante lo que pudieron considerar una herejía en momentos muy tardíos, ya en el Imperio bizantino, queda reflejado en la imagen que los mandeos esbozan sobre Cristo en este texto:

Entonces Cristo, el tentador, vendrá bajo otra forma; se pondrá entre vosotros y dirá: <<Yo marcho sobre las aguas; venid a mi lado, que no os hundiréis $>$.

No le hagáis caso y no le creáis; si os obliga y mata a alguno de vosotros, no temáis. Si os mata, lo que mata es vuestro cuerpo, pero vuestra alma estará en la región de la luz; no os asustéis, no temáis, no tengáis miedo de Cristo, el Bizantino (rumaia), el deleznable, ni del que altera las palabras (malalia) ${ }^{22}$.

Las acusaciones contra los cristianos llegan incluso a cuestionar la resurrección de Cristo, calificándola de engaños mágicos.

Más aún, fabricará una escalera; la tenderá desde la tierra hasta el cielo; subirá, bajará, volará entre el cielo y la tierra y os dirá: <<Mirad cómo yo vengo del cielo; soy vuestro Señor $>$. Pero no le creáis, porque la escalera de Cristo está hecha de engaño, de magia y de encantamiento ${ }^{23}$.

A lo que seguirán nuevas exhortaciones y advertencias a no creer en Cristo y prevenir de sus seguidores.

Para los mandeos la procreación posee una gran importancia, por lo que el celibato o la virginidad, elegida o impuesta, significa prácticamente un pecado o sacrilegio; asimismo, quedaban prohibidas las formas de autotortura o mortificación ni practicar la

${ }^{22}$ Ginza, I, II, 54.

${ }^{23}$ Ginza, I, II, 54- 55. 
abstinencia, no solo sexual, sino también en lo que concierne a los ayunos; por lo que las críticas al cristianismo se centrarán, sobre todo, en el monacato, concibiéndolo como una forma perversa de manifestación socio- religiosa.

Abandonarán sus casas y se harán monjes y monjas. Cortarán su semilla entre sí; de las mujeres con los hombres y de los hombres con las mujeres; cortarán su semilla y su descendencia en el mundo; impondrán ayuno a sus bocas y los atarán con ataduras; cortarán la comida y la bebida de sus bocas y cortarán los vestidos blancos de sus cuerpos.

$$
(\ldots)
$$

Se les hace morar en soledad y vienen espíritus femeninos nocturnos $\left(\right.$ liliata $\left.^{24}\right)$ junto a ellos; se acuestan con ellos; reciben de ellos la semilla, quedan embarazadas y nacen súcubos e íncubos que caen sobre los humanos.

No toman medicina, remedio o curativo, sino que se ponen de la semilla, de las basuras e inmundicias de aquellos monjes y se frotan.

Hay entre ellos quienes abandonan y hay entre ellos quienes no $\operatorname{abandonan}^{25}$.

A todo ello le seguirá una contraposición entre Cristo y Juan Bautista, al que tienen como fundador de su secta ${ }^{26}$. La pretendida venganza contra el cristianismo por parte de

\footnotetext{
${ }^{24}$ Esta designación de los espíritus malvados femeninos proviene de Lilith o Lilitu, que según la mitología hebrea fue la primera esposa de Adán (según este mito Eva sería la tercera), nacida del estiércol y la grava, incapaz de someterse a la voluntad de Adán, Dios le dio alas y, junto al mar muerto, se unió al demonio Asmodeo, siendo los padres de un linaje de demonios nocturnos y sexuales denominados súcubos (femeninos) e íncubos (masculinos). Raramente se menciona el nombre de Lilith en la Biblia, Is 34- 14 (simbolizada por la lechuza) o en el Talmud. Ver, MARCOS CASQUERO, 2009.

${ }^{25}$ Ginza, I, II, 55- 56. Entre las críticas a la virginidad puede leerse: "Espíritu, su madre, se sentirá orgullosa de él. Con su hermosa apariencia y con su magia seducirá a los humanos. A su voz, dejarán las novias la cámara nupcial y la parturienta la casa del parto". Ginza, I, II, 59.

${ }^{26}$ Ginza, I, II, 57- 58. Según Hans Jonas, en esta secta Juan Bautista constituiría la sustitución y oposición a Cristo. JONAS, 2003, 68.
} 
los mandeos vendrá cuando en la hora del juicio, Anus Utra ponga al descubierto la mentira de Jesús, lo juzgue y lo condene. Si antes identificaba al Jesús histórico con Anus Utra, ahora Cristo es sometido y juzgado por este personaje sobrenatural mandeo, desdoblando el Cristo de los Evangelios al sustituirlo por Anus Utra. Pero esta identificación será de nuevo desmentida en el Ginza II, donde Cristo se revela junto con Anus Ziua, reconociendo finalmente los milagros y primacía del segundo, quedando el Nazareno nuevamente desprestigiado ante el poder y conocimientos de otro ser sobrenatural mandeo ${ }^{27}$.

Sobre las diferentes sectas de Cristo, el autor del Ginza, afirma que todas ellas llevan a la mentira y arrojan necedad al mundo, que todo lo que obró Cristo acabará el último día. Para ello se apoya en los conflictos entre católicos y herejes que, secularmente, pudieron observar tanto los mandeos como otras religiones adversativas del cristianismo, así como las múltiples interpretaciones que realizaban sobre las Sagradas Escrituras, incapaces de llegar a un consenso aún perteneciendo a la misma religión.

Las puertas que creó Cristo, todas ellas, unas a otras, se acusan de mentira; todas ellas se acusan de mentira, unas a otras, y en una sola palabra (mamla) no se mantienen; no se mantienen en una sola palabra, porque son obra de la mentira (qrita $d$ - siqra).

Pervirtieron las palabras, la realidad que la Primera había obrado; pervirtieron las palabras y necedad arrojaron en el mundo; necedad en el mundo arrojaron.

Lo que neciamente obró Cristo, todo ello ciertamente acabará en el último día ${ }^{28}$.

Cristo aparece, además, como señor de la sexta guardia, estación o purgatorio, según la escatología mandea. Allí se detienen las almas de los cristianos, que negaron la Vida y siguieron a Cristo. Se presenta a un Cristo oscuro, deleznable, mentiroso y corruptor de

\footnotetext{
${ }^{27}$ Ginza, II, XXXVII.

${ }^{28}$ Ginza, I, VI, 120.
} 
las almas. Las almas de sus fieles congregadas en este estado espiritual, cual rebaño, reclamaban a Cristo, su pastor, agua, pero él se negaba a dársela (simbolismo del falso bautismo cristiano), al igual que se oponía a darles una segunda vida a sus seguidores (incapacidad de cumplir su promesa de la resurrección de la carne). En definitiva, en el itinerario espiritual, según las creencias mandeas, a Cristo se le reserva el lugar de un gran embaucador y estafador ${ }^{29}$.

El bautismo de Manda d- hiia por Juan el Bautista ${ }^{30}$, parece sustituir a Jesús por el salvador particular del mandeísmo y, aunque en la forma no se parece, prácticamente en nada a los relatos evangélicos de Mt 3, 14- 15 y Jn 1, 29- 31; en esencia, el relato del Ginza parece reproducir de forma midrásica o a modo de comentario, la inicial reticencia del Bautista a bautizar a Jesús, al que reconoce como superior a él. La imagen negativa que el mandeísmo proyecta sobre Jesucristo no le abandona en el relato, al que sigue considerando como ángel liberador o ángel exterminador.

Acerca del origen astral de las religiones, en el Ginza se vuelve a arremeter contra el monacato. Acusa a monjes y monjas cristianas de ser una secta fundada por Saturno, identificado con el Dios de los judíos, así como de un rosario de perversiones, aberraciones y blasfemias de todo tipo, incluso de mantener relaciones sexuales con diablos, demonios y agentes femeninos nocturnos $(\text { liliata })^{31}$.

Sobre el origen solar de algunas religiones vuelve a hablar despectivamente del cristianismo, ahora como transgresores de tabúes religiosos y alimenticios, corruptores sexuales y proabortistas:

Os voy a hablar del Sol (samis) y de la captura que capturó. De él proceden los yazuqueos. Se transfiguran en mi figura, el hombre sobrenatural; se sujetan sus varas (bursma) a modo de cruz sobre los hombros e invocan el nombre de Jesús; celebran el uasqa, a semejanza de mi pan y mi bebida, el hombre sobrenatural; tienen el banquete (`druna) a semejanza de mi función de subida (masiqta); veneran mucho al agua y

\footnotetext{
${ }^{29}$ Ginza, I, IX, 184- 186.

${ }^{30}$ Ginza, I, X, 189- 196.

${ }^{31}$ Ginza, I, XIII, 222- 223. Nueva referencia a los súcubos e íncubos.
} 
el fuego; comen de lo muerto y dicen que Dios lo ha matado; se acuestan con sus madres y sus hermanas; se imponen silencio; toman ropas de mujeres en menstruación, se visten y cubren con ellas y dicen: $<<$ No nos hacemos impuros $\gg$. No reconocen sus propias aberraciones. Cuando sus mujeres expulsan sus fetos de su vientre, los desuellan, los ponen en siete pozos, echan orines de animales sobre ellos y los restriegan con un paño $^{32}$.

Las críticas al monacato masculino y femenino, así como al cristianismo en general se continúan en las llamadas capturas de Venus. A las acusaciones precedentes y clásicas de la polémica mandeo- cristiana se añaden nuevas críticas, esta vez, contra la veneración de las reliquias mortuorias de los santos, algo que la mentalidad mandea, obsesiva con la purificación ritual, resultaba repugnante, aberrante e impuro, pues hay que recordar que esta secta judaica adora la vida, por lo que incluso el luto estaba prohibido:

Más les dice Espíritu: $<<$ A cualquiera que se le muera el padre o la madre o el hijo primogénito, el predilecto (iaqir), ponedlos en vuestra casa; no los echéis fuera; les dice aún otro misterio: $\ll$ A cualquier filósofo (pilasupa), católico (katulica), metropolita (mitrapulita), obispo (apisqupa), presbítero (qasa) o diácono (samasa, servidor) que se muera entre vosotros, ponedlo en la iglesia (qlasia), veneradlos, rogad por ellos y no los echéis de vuestro oratorio (bit masgdaikun). También a cualquier visitador (saiura), estudiante (sakula) o guardián (sahara) que os haya dejado, siendo instruido en los milagros (tihrata) de Cristo, ponedlo en el recinto del altar (bit madbha) y no lo tengáis por impuro >> ${ }^{33}$.

\footnotetext{
${ }^{32}$ Ginza, I, XIII, 223- 224.

${ }^{33}$ Ginza, I, XIII, 226- 227.
} 
La magia, la hechicería y la lascivia se entremezclan, a veces en una confusa descripción de la liturgia cristiana, predominando como denuncia en los textos mandeos.

El bautismo de Manda d-hiia por Juan el Bautista, trasposición o comentario de los textos evangélicos precedentes, toma una nueva dimensión e interpretación, mucho más clara en el segundo libro del Ginza, donde el diálogo entre Juan (mítico fundador de la secta mandea) y Jesús (como fundador del cristianismo ${ }^{34}$ ) se plantea, bajo la forma de reticencia de Juan a bautizar a Jesús ante las tres peticiones del Nazareno, la polémica anticristiana que sostuvo el mandeísmo de forma más abierta y clara, mostrándose ambas partes siempre según la concepción mandea del cristianismo.

Entre las objeciones del Bautista encontramos acusaciones a Jesucristo por incitar a la virginidad y al celibato y por derogar el sábado judío. Afirma, además, que mintió a los judíos, por lo que no quiere ser copartícipe con él y su secta.

Parece que Juan no cree en la conversión sincera de los pecadores, pues ante personas que por su naturaleza u oficio no pueden ser buenos, según el Bautista; Jesús dice lo contrario y argumenta: "Piedra que se ablanda con aceite: es el hereje que baja del monte, abandona sus hechicerías y abandona sus brujerías, y cree en la Vida poderosa; encuentra a un huérfano y la da de comer hasta saciarlo y llena el cesto de la viuda"35.

Pese a que Cristo es llamado embustero por la casa de Abatur, finalmente, Juan accede a bautizar a Jesús. Aquí se reproduce cierta semejanza entre el bautismo de los Evangelios sinópticos y este breve texto, pero todos los elementos simbólicos del mismo parecen forzados e incomprendidos, al proceder de tradiciones ajenas a esta secta gnóstica: "Espíritu tomó forma de paloma y trazó en el río una cruz; trazó una cruz en el río, y las aguas quedaron de varios colores, y dijo: <<Río me has santificado a mí y has santificado a mis siete hijos $>>, 36$.

Asimismo, trata de forma peyorativa a Pablo y, por ende, al sacerdocio y sus ritos que él representa, para acabar el texto con una nueva advertencia contra los cristianos para prevenir a los mandeos, tanto de sus servidores como del mismo Dios cristiano para que

\footnotetext{
${ }^{34}$ Realmente, hemos de considerar a Pablo de Tarso como verdadero fundador del cristianismo, siendo Cristo el sujeto soterológico de dicha religión.

${ }^{35}$ Ginza, II, XXI, 107.

${ }^{36}$ Ginza, II, XXI, 108.
} 
se abstuvieran, en definitiva, de su culto, guardando así su idiosincrasia en un mundo y tiempo hostil.

Cuidaos, hermanos míos; cuidaos, amigos míos; cuidaos, hermanos míos, de los cristianos (rumaiia, <<romanos o bizantinos〉>), que se parecen a la cruz (saliba) que ellos fijan en las paredes $\mathrm{y}$, puestos, adoran al crucificado (qurqsa).

Cuidaos, hermanos míos, del dios (alaha) que fabricó el carpintero; si al dios lo fabricó el carpintero, entonces ¿al carpintero quién lo fabricó $?^{37}$

Cristo vuelve a tomar una faceta siniestra en un nuevo diálogo con Juan el Bautista, que habla como fundador del mandeísmo. Jesús le pregunta sobre la muerte y le pide una semejanza de la misma:

La cuchilla de Sauriel ${ }^{38}$, ¿a qué se parece su figura? Cuando sale el alma del cuerpo, dime, ¿de qué se reviste, y a qué se parece dentro del cuerpo mortal? ¿Se parece acaso el alma a la sangre ${ }^{39}$ que está caliente en el cuerpo y luego se queda coagulada? ¿Se parece acaso el alma al viento que se desata en el monte, se muere y queda calmo? ¿Se parece acaso el alma al rocío que cae sobre los frutos y perece $?^{40}$

A lo que sigue una explicación escatológica de Juan, no falto de un arrebato de impotencia e ira contra las preguntas blasfemas de Jesús, con un tono punitivo y maldiciente: "Cuando Cristo dijo esto, Juan lanzó un grito, se le vinieron las lágrimas a los ojos sin parar, y dijo: < < ¡Ojalá demande el excelso Rey de la luz la parte de las heces!>>"41.

\footnotetext{
${ }^{37}$ Ginza, II, XXI, 109.

${ }^{38}$ Sauriel (Samael en la tradición bíblica hebrea), es el ángel de la muerte para los mandeos.

${ }^{39}$ Dt. $12,23$.

${ }^{40}$ Ginza, II, XXIV, 123.

${ }^{41}$ Ginza, II, XXIV, 123.
} 
Si para los mandeos Jesucristo es un ser negativo, eso no evitó que adoptaran al personaje bíblico (y extra-bíblico) de María, bajo el nombre de Miriai ${ }^{42}$, como símbolo del mandeísmo. Es evidente, que María aquí no juega el papel de madre de Cristo e intercesora del mismo pues, es necesario recordar que, la madre de Jesús es Espíritu Santo para los mandeos. Ya que Miriai no podía desempeñar en el mandeísmo su función intercesora en el plano soterológico y escatológico como en el caso del catolicismo, su rol se limitó a ser el prototipo de mujer ideal, fiel y devota mandea desde su conversión del judaísmo sacerdotal en que fue instruida, tal y como fue concebida en guardando para esta mujer un lugar especial en la tradición mandea, tal y como hiciera, en líneas generales, el cristianismo y el islam, aunque la dimensión espiritual de María quedó más pronunciada en estas dos últimas religiones.

Las líneas argumentales de la vida de Miriai están basadas en los relatos de la niñez y juventud de María según el Protoevangelio de Santiago y el Evangelio de PseudoMateo.

Pese a haberse educado en el Templo de Jerusalén, ella abandonará el judaísmo por la secta mandea, lo que le recriminará su padre, llegando a insultarla por el oprobio que hacía pasar a su familia. La respuesta rebelde de Miriai será reafirmarse en su nuevo credo, reconociendo a Conocimiento- de- la- Vida y a la Vida, repudiando abiertamente del judaísmo y el sacerdocio en que fue educada ${ }^{43}$.

Miriai se convertirá en un símbolo de la resistencia mandea en las persecuciones judías contra el mandeísmo. A su vez, es la imagen de la mujer predicadora, transgresora y santa al mismo tiempo. Si antes enseñaba a leer e instruía en la Torah a las niñas, ahora hasta los peces y los pájaros ${ }^{44}$ acudían a verla hablar de la verdad gnóstica del mandeísmo. Pero su imagen icónica va más allá, siendo adversaria del judaísmo clásico, acusándolos de hipócritas por adorar la bóveda celeste o, lo que es lo mismo, practicar la astrología. Incluso traerá una mística venganza contra los judíos, cuando un águila

\footnotetext{
${ }^{42}$ A cerca del personaje mítico- religioso de Miriai ver BUCKLER, 2002, 49- 58.

${ }^{43}$ Ginza, II, XXV.

${ }^{44}$ La santidad mandea se expresa en líneas semejantes a otras religiones como el budismo, el cristianismo y el islam. En nuestra cultura occidental tenemos muy presente la imagen de Francisco de Asís predicando a las aves del cielo (Florecillas, 22) o a San Antonio de Padua predicando a los peces (Florecillas, 40), tal y como Miriai es representada en este texto mandeo uniendo ambos arquetipos de la santidad en comunión con la naturaleza, presentando una armonía de la creación, donde todo tiene su lugar y las verdades de la fe no se oculta a nada ni nadie, cumpliendo cada uno la función por la que fueron concebidas por la divinidad.
} 
hunda los judíos en las aguas abismales y $\operatorname{lodos}$ fétidos ${ }^{45}$, mató a los discípulos judaicos en Jerusalén y destruyó el Templo de la misma ciudad, mientras ella conversaba con los sacerdotes judíos junto al Éufrates ${ }^{46}$.

Miriai es, sin más, un icono o arquetipo de santidad mandea; mientras que Jesús, completamente ajeno y opuesto a la figura de María/ Miriai, es una personificación sobrenatural o preternatural del mal.

\section{Oracional mandeo}

En estos escritos breves asociados a los principales ritos y sacramentos mandeos también existen advertencias, similares a las ya vistas en el Ginza, contra el cristianismo y las desviaciones y errores religiosos y, por tanto, trascendentales y cosmológicas, que conllevan.

No obstante, las advertencias, en este tipo de documento cultual, son mucho menores y genéricas. Véase, por ejemplo, el siguiente fragmento de la plegaria titulada Al principio de la creación:

Cuidaos, hermanos míos; cuidaos, amigos míos; cuidaos, hermanos míos, de Jesús, el falso (batla) Mesías, del que trastoca las imágenes y altera las palabras (mamlala) de mi boca. Si os cuidáis, hermanos míos; si os cuidáis, amigos míos; si os cuidáis hermanos míos, cuando salgáis de vuestro cuerpo yo os serviré de ayuda; de ayuda, de apoyo del lugar de las tinieblas al lugar de la luz ${ }^{47}$.

El Oracional mandeo recuperará a la Miriai arquetípica del Ginza, iniciada y devota, como enamorada de Conocimiento- de- la- Vida (Manda $d$ - hiia) ${ }^{48}$, en un plano que va más allá del gnosticismo introductorio y se vuelca en un sentimiento místico que experimenta la mujer conversa y plenamente conocedora de la verdad en su más pura esencia espiritual.

\footnotetext{
${ }^{45}$ Aguas primordiales del caos de las que está compuesto parte del infierno mandeo que tuvieron un papel activo en la creación.

${ }^{46}$ Ginza, II, XXVI.

${ }^{47}$ Oracional mandeo, XLVI, 158.

${ }^{48}$ Oracional mandeo, $\mathrm{L}$.
} 
Miriai describirá a Conocimiento- de- la- Vida como un ser excelso que resucita muertos $^{49}$ y sana enfermos ${ }^{50}$, que no tiene comparación con otro $\operatorname{ser}^{51}$. No obstante, lo genuino de la pretensión mandea se rompe si visualizamos brevemente la historia de las religiones, donde es posible encontrar hombres taumaturgos y resucitadores a lo largo de múltiples tradiciones antiguas, que probablemente, contribuyeron a inspirar la imagen soterológica y dadora de vida de Manda $d$ - hiia, desde Isaías ${ }^{52}$ en la tradición hebrea, Apolonio de Tiana ${ }^{53}$ en la griega y, sobre todo, Jesús de Nazaret ${ }^{54}$, a quien sin duda, el salvador mandeo debe mucho como construcción religiosa con pretensiones históricas, pues tan solo hay que leer los Evangelios sinópticos para encontrar más semejanzas de las que se pudiera esperar entre individuos de religiones tan diferentes.

\section{Conclusiones.}

Hemos podido apreciar cómo las críticas y acusaciones del mandeísmo hacia el cristianismo, en el contexto de la polémica anticristiana, muy abundante en los textos religiosos de los mandeos, se centraban en dos puntos o pilares que estructuraban toda línea adversativa: Cristo y los cristianos.

Las blasfemias y oposiciones a la figura de Jesús estaban profundamente marcada por las actuaciones de la comunidad cristiana sobre la mandea y, hemos de ver la crítica de los mandeos hacia los cristianos, ya sean católicos, nestorianos o maniqueos, como una autodefensa y reafirmación de la comunidad mandea, reforzando una identidad que era atacada por el proselitismo cristiano y coartaba la libertad de los mandeos (tal vez, por este motivo, Cristo es visto como señor de los astros). En la misma línea podríamos enmarcar la crítica antiislámica presente en los mismos textos analizados.

Las críticas se centraron en la falta de moral del monacato y los cristianos en general, con una fuerte acentuación en los comportamientos sexuales, así como asesinatos, canibalismo y transgresiones religiosas aberrantes para la sensibilidad mandea.

\footnotetext{
${ }^{49}$ La resurrección de los muertos, como tema religioso de la Antigüedad pagana, judía y cristiana, así como su evolución conceptual en dicho marco cronológico, ha sido ampliamente estudiado en la obra de WRIGHT, 2008.

${ }^{50}$ Sobre la taumaturgia y sus protagonistas véase: PIÑERO, 1997.

${ }^{51}$ Oracional mandeo, LI.

${ }^{52} 1$ Re 17, 17- 24. Resurrección del hijo de la viuda de Sarepta por Isaías.

${ }^{53}$ Además de taumaturgo y exorcista, Apolonio de Tiana resucitó a una muchacha (narración con paralelos bíblicos en Mc 5, 40 y Lc 7, 11) y a una mujer llamada Sóstrata. Philostr. VA, IV, 45.

${ }^{54}$ Sobre Jesucristo, el Nuevo Testamento, así como los escritos apócrifos neotestamentarios pasan de la construcción literaria hagiográfica de este personaje histórico a la divinización o, propiamente dicho, el reconocimiento de Cristo como hipóstasis divina o Dios mismo.
} 
Prácticamente, todas estas acusaciones podemos leerlas en las largas listas de injurias proferidas por parte de los paganos hacia los cristianos a lo largo de la Antigüedad Tardía, lo que sí es una novedad es la forma en la que se estructuran y argumentan, pues parte de la moral y valores mandeos. Igualmente desbordaron su imaginación creando difamaciones e injurias a medida contra los cristianos por la necesidad a la que se enfrentaron, es decir, sobrevivir en una situación hostil y en minoría frente a los agentes institucionales y religiosos de un Imperio, como era el romano, con deseos expansionistas incontrolados, que imponían su religión de formas diversas, ya fuera pacíficamente o por la fuerza, según las circunstancias lo solicitaren.

Sin embargo, no existieron obstáculos insalvables para que el sincretismo con el cristianismo y otras formas de religión hicieran posible que el mandeísmo aceptara y se apropiara de figuras religiosas como la de Juan el Bautista y Miriai o María, sin que ello supusiera una anexión peligrosa que diluyera los principios básicos gnósticos, compartidos con el resto de culturas y religiones coetáneas, y poder así adaptarlos a las necesidades religiosas de los mandeos en un plano eternamente conflictivo, debido al rechazo a la convivencia con las demás sectas e instituciones religiosas. Idiosincrasia, evidentemente, compartida con las culturas y religiones que la rodeaban.

\section{Fuentes:}

BERMEJO RUBIO, F. y MONSERRAT TORRENTS, J. (ed.), El maniqueísmo. Textos y fuentes. Madrid, 2008.

Biblia de Jerusalén, Bilbao, 2009.

Corán, Cortés, J (ed.), Barcelona, 2007.

DE JESÚS, T. Obras Completas, (transcr., introd. y n. de E. DE LA MADRE DE DIOS, (OCD) Y O. STEGGINK, (O. CARM), Madrid, 2012.

DE SANTOS OTERO, A. (ed.), Los evangelios apócrifos, Madrid, 2009.

EPIFANIO DE SALAMINA, Panarion: The Panarion of Epifanius of Salamis, Book I, sects. 1- 46, (translated by F. WILLIAM), Leiden. Boston, 2009, and Book II, 2013.

FILÓSTRATO, Vida de Apolonio de Tiana, (trad., introd. y n. de A. BERNABÉ PAJARES), Madrid, 2008.

GUERRA, J. A. (ed.), Florecillas, Madrid, 2010.

ISIDORO, Etimologías, (text. lat., ver. esp. y n. por J. OROZ RETA, M.- A. MARCOS CASQUERO y M. C. DIAZ Y DIAZ), Madrid, 2009. 
LÓPEZ FERNÁNDEZ, E. (ed.), Escritos mandeos, Madrid, 2013.

PIÑERO, A. (ed.), Todos los Evangelios, Madrid, 2009.

\section{Bibliografía}

ALKHALIFA, W. S. "Aproximación a los sabeos (mandeos), minoría milenaria de medio oriente". Estudios: Centro d Estudios Avanzados, $\mathrm{N}^{\circ}$. Extra 0 (Número especial), (2010) 123-129.

BUCKLEY, Jorunn Jacobsen. Ancient Texts and Modern People, Oxford, 2002.

BAYET, J. La Religión Romana. Historia política y psicológica, (trad. esp. de M. A. ELVIRA), Madrid, 1984.

BERMEJO RUBIO, F. El maniqueísmo. Estudio introductorio, Madrid, 2008.

BROWN, P. Body and society. Men, women and sexual renunciation in early christianity, New York (USA), 2008.

GARCÍA COLOMBÁS, M. (O. S. B.) El monacato primitivo, Madrid, 2004.

JONAS, H. La religión gnóstica. El mensaje del Dios Extraño y los comienzos del cristianismo, (trad. esp. M. Gutiérrez), Madrid, 2003.

LÓPEZ FERNÁNDEZ, E. "El cuerpo celeste en los Escritos Paulinos y en el Mandeismo: todos seremos transformados". Studium Ovetense: Revista del Instituto Superior de Estudios Teológicos del Seminario Metropolitano de Oviedo, No. 30, (2002) 323-348.

LÓPEZ FERNÁNDEZ, E. "Koinonía cristiana y koinonía mandea: lectura de 1 Jn 1, 3 y otros textos neotestamentarios a la luz de los escritos mandeos". Studium Ovetense: Revista del Instituto Superior de Estudios Teológicos del Seminario Metropolitano de Oviedo, $\mathrm{N}^{\mathrm{o}} .28,(2000) 7-42$.

MARCOS CASQUERO, M. A. Lilith. Evolución histórica de un arquetipo femenino, León, 2009.

PIÑERO, A. En la frontera de lo imposible. Magos, médicos y taumaturgos en el Mediterráneo Antiguo en tiempos del Nuevo Testamento, Córdoba, 1997.

PUECH, H. CH. Sobre el maniqueísmo y otros ensayos, (trad. esp. M. Cucurella Miquel), Madrid, 2006.

RUSELL, G. Heirs to forgotten kingdoms. Journeys into the dissapearing religion of the Middle East, New York, 2015.

SÁNCHEZ VALENCIA, R. "Una resistencia de dos mil años: los mandeos: Hacia una identificación de un primer sustrato doctrinal de la religión Mandea por medio de la identificación de una obra apologética de San Agustín: Adversarius Legis et Prophetarum". Historia y grafía, No . 13, (1999) 187-201. 
SCOTTEN, ALI. G. Magic and Inter-Communal Relations in Sasanian Iraq. The Case of the Incantations Bowls, Chicago, 2007.

SMITH, D. E. Del Simposio a la Eucaristía. El banquete en el mundo cristiano antiguo, (trad. esp. de A. MOLINER FERNÁNDEZ), Navarra, 2009.

VIZMANOS, F. B. Las vírgenes cristianas de la Iglesia Primitiva. Estudio histórico y Antología patrística, Madrid, 2009.

VV. AA. Divinitation and Interpretation of Signs in the Ancient World, Chicago, 2010.

WRIGHT, N. T. La Resurrección del Hijo de Dios, (trad. esp. de J. P. TOSAUS ABADÍA; A. y B. MILLÁN RISCO), Navarra, 2008. 